\title{
Rapid Detection of Bovine Herpes Virus Type 1 (BoHV-1) in Egyptian Dromedary
} Camels

\author{
Ramzy H. Hamouda ${ }^{1}$ and Marwa F. Mahmoud ${ }^{2}$ \\ ${ }^{1}$ Mastitis and Neonatal Disease Department, Animal Reproduction Research Institute (ARRI), Agriculture \\ Research Center (ARC), Giza, Egypt. \\ ${ }^{2}$ Virology Unit in Reproductive Disease Department, Animal Reproduction Research Institute (ARRI), \\ Agriculture Research Center (ARC), Giza, Egypt. \\ Corresponding Author E-Mail: asiamarwa1911@gmail.com
}

\begin{abstract}
Bovine herpesvirus 1 (BoHV-1) is known to cause reproductive disorders in Sudanese camels. Egypt imports about $90 \%$ of its camels from Sudan, and the rest from Somalia. The BoHV1 is a viral disease of bovines that can be transmitted to camel, sheep, and goat. Due to the absence of anti-camel conjugated with fluorescein isothiocyanate (FITC) in the market, we used protein-A conjugated with FITC which binds to the $\mathrm{Fc}$ region of IgG of many animal species. We, therefore, prepared rabbit anti-camel IgG conjugated with FITC and compared it with protein-A conjugated with FITC to the specificity and sensitivity of these compounds in IBR detection from 35 nasal swaps in imported Egyptian dromedary camels. The sensitivity and specificity of the prepared anti-camel IgG FITC and protein-A FITC were compared using Virus Neutralization Test. The labeled protein concentration in the prepared anti-camel conjugate was $2 \mathrm{mg} / \mathrm{ml}$ which was considered as an acceptable value. The degree of labeled protein (DOL) was $5.74 \mathrm{~cm}-1 \mathrm{M}-$ 1 and optimal DOL usually fell between 2 and 10 . The titer of the prepared anti-camel IgG-FITC was 3,125. The prepared anticamel IgG-FITC and protein-A-FITC showed a sensitivity of 93.75 and $90.9 \%$, and a specificity of $71.43 \%$ and $62.5 \%$, respectively. Our findings show no significant difference between protein-A conjugated FITC and prepared anti-camel IgG-conjugated FITC in the rapid diagnosis of BoHV-1 in Egyptian dromedary camels.
\end{abstract}

Original Article:

DOI: $\underline{\text { HTTPS://DX.DOI.ORG/10.2 }}$ 1608/JAVS.2020.85587

Received : 15 March, 2020.

Accepted : 05 April, 20020.

Published in April, 2020.

This is an open access article under the term of the Creative Commons Attribution $\quad 4.0 \quad$ (CC-BY) International License . To view a copy of this license, visit http://creativecommons.org/licenses/ by/4.0/

Keywords: Anticamel FITC, BoHV-1, dromedary, IBR, SNT

J. Appl. Vet. Sci., 5(2 ): 61- 66.

\section{INTRODUCTION}

Bovine herpesvirus 1 (BoHV-1) is a member of the genus Varicellovirus in the Alphaherpesvirinae subfamily which belongs to the family Herpesviridae, order Herpesvirales (Andrew, 2010) Globally, BoHV1 is known to cause various infectious diseases in cattle including rhinotracheitis, vaginitis, balanoposthitis, abortion, conjunctivitis, and enteritis. It also contributes to shipping fever, also known as bovine respiratory disease (BRD) (Raaperi et al., 2014). The virus spreads through sexual contact, artificial insemination, aerosol transmission, or even through the placenta (Sunil, 2000). BoHV-1 can cause both clinical and subclinical contaminations, depending on the pathogenicity of the viral strain. Although the virus is rarely life-threatening, it constitutes a financial liability for cattle farmers, as pollution can cause the spread of infection and a drop in production because of increasing the abortion rate (Van et al., 1993).

Like other herpesviruses, BoHV-1 causes deep-rooted inactive contamination and scattered shedding of the virus in all animal discharges (OIE, 2018). Egypt is one of the most important camelrearing countries, with hundreds of thousands of camels imported yearly as 'butcher' animals to provide camel meat for the Egyptian market. These camels are primarily imported from Sudan and Somalia. These vehicles were categorized by street, foot, or ocean (Helena 2018). Previous research has shown that camels coming from Sudan are naturally exposed to 


\section{Rapid Detection Of Bovine Herpes Virus Type 1......}

BoHV-1 and they confirmed the infection by using the fluorescent antibody test (FAT) and enzyme-linked immunosorbent assay (ELISA) (Intisar et al., 2009). Serological surveys were also performed in Iran to detect antibodies against (BoHV-1) in dromedary camels. (Raoofi et al., 2012).

A rapid diagnosis can effectively control disease spread and decrease economic losses associated with abortion. The indirect fluorescent antibody test (IFA) is a semi-quantitative, sensitive, and rapid serum antibody detection test for immunoglobulin M (IgM) and $\mathrm{G}$ (IgG) (Messenger and Rupprecht, 2015). Conventional methods for detecting the herpes virus have been compared, such as fluorescent antibody testing (FAT) and virus isolation (VI). Although FAT is less sensitive, it should always be used as an early diagnosis routine (Madhavan et al., 2003).

An optimal fluorescein protein ratio $(\mathrm{F}: \mathrm{P})$ was calculated to know the maximum labeled antibody with fluorescein. This procedure can be used to prepare functional, labeled antibody reagents with a defined activity and can help in quantitative applications where the stoichiometry and functionality of the labeled antibody are critical (Vira $\boldsymbol{e t} \boldsymbol{a l}$., 2010). Therefore in this study, we prepared rabbit anti-camel IgG conjugated with Fluorescein isothiocyanate to diagnose BoHV-1 in Egyptian dromedary camels.

\section{MATERIALS AND METHODS}

\section{Animals}

Animal maintenance and care conformed with recommended International Guiding Principles for Biochemical Research Involving Animals (National Research Council ,US, Institute for Laboratory Animal Research, 2004.

\section{Camels}

- Three liters of blood were collected in a sterilized capped bottle from three camels in a slaughterhouse. They were stored in the refrigerator overnight at $4^{\circ} \mathrm{C}$. The serum was separated and tested against BoHV-1 antibodies using the serum neutralization test.

- Nasal swabs were collected from 35 pasture camels on the desert road of El Sadat city.

\section{Rabbits}

Ten unvaccinated male rabbits aged between 1.5-2 months and weighing between 2-3 $\mathrm{Kg}$ were obtained from the laboratory animals unit at the Animal Reproduction Research Institute (ARRI), Haram, Giza.

\section{Virus}

A local strain of BoHV-1 propagated in Madin-Darby bovine kidney cells (MDBK) with a titer 106 TCID50/ml was used for antibody detection in the serum neutralization test. It was provided by Virology Unit, Department of Animal Reproduction Diseases, Animal Reproduction Research Institute (ARRI)

\section{Virus Neutralization Test (VNT)}

Two-fold serial dilutions of the sera (1:2$1: 128)$ were performed in the presence of 100 TCID 50/ml of BoHV-1 in the presence of a positive reference control, as previously described by Martinelle et al., (2011). The neutralizing antibody titer of the collected camel sera was defined as the reciprocal of serum dilution, causing a $50 \%$ reduction in cytopathic effect in (MDBK) cells.

\section{Preparation of camel IgG}

Five hundred $\mathrm{mg}$ of ammonium sulfate was added to $1 \mathrm{~L}$ camel serum to reach $50 \%$ saturated ammonium sulfate (SAS) solution to precipitate immunoglobulins, which were dialyzed by $15 \mathrm{mM}$ of phosphate-buffered saline (PBS). The absence of SAS in the final product was tested using barium chloride. Immunoglobulins were concentrated using Polyethylene glycol according to the method of Abd El Hafez et al. (2010).

\section{Purification of immunoglobulins}

The purity of $\operatorname{IgG}$ was confirmed using protein-A sepharose gel with eluting buffer $0.1 \mathrm{M}$ glycine. It was carried out according to the methods of Abd El Hafez et al. (2010). The protein contents of immunoglobulins were estimated according to the methods described in Lowry et al. (1951). Sodium dodecyl sulfate-polyacrylamide gel electrophoresis (SDS-PAGE) was performed in $10 \%$ polyacrylamide gels according to Laemmli (1970). Buffer containing 2-mercaptoethanol was mixed with camel IgG and loaded to the gel. Then, the gel was stained with Coomassie Brilliant Blue dye and molecular weights of bands were calculated using Protein marker supplied by Sigma-Aldrich.

\section{Mixing camel IgG with an adjuvant}

Montanide $^{\mathrm{TM}}$ oil ISA 206 was obtained from the Central Laboratory for the Evaluation of Veterinary Biologists (CLEVB), Agriculture Research Center (ARC), and Giza, Egypt. Montanide adjuvant ISA 206 was added in a $1: 1(\mathrm{v} / \mathrm{v})$ ratio into the prepared camel IgG and was mixed by homogenization according to Aslam et al., (2013).

\section{Rabbit immunization}

The purified camel $\operatorname{IgG}$ was mixed with an equal volume of ISA 206 montanide oil and $80 \mu \mathrm{g} / \mathrm{kg}$ was used to immunize the rabbits four times weekly. Injections were done subcutaneously at different locations. The last dose was given without adjuvant according to Tendler et al., (1991). Anti-camel IgG was titrated against camel serum using the AGID test according to Ouchterlony (1962).

\section{Labeling of anti-camel with FITC}

(2004)
This procedure is according to Hanan et al., 
1. Two $\mathrm{mg} / \mathrm{ml}$ of protein was prepared in $0.1 \mathrm{M}$ carbonate sodium buffer, ( $\mathrm{pH} 9$ ). The buffer was kept at $5^{\circ} \mathrm{C}$ for no more than one week (freshly prepared).

2. The protein to be conjugated should be free from contaminating proteins; therefore, it was first tested. The protein solutions were prepared in buffers that excluding sodium azide or amines such as Tris or glycine, as these compounds inhibit the reaction to the mark. If amines or sodium azide were present in the buffer, the protein solution was dialyzed against PBS $\left(\mathrm{pH}\right.$ 7.4) overnight between 0 and $5^{\circ} \mathrm{C}$. Note that dialyzing at high $\mathrm{pH}$ values $(>8.0-8.5)$ may be harmful to some proteins.

3. The FITC was dissolved to $1 \mathrm{mg} / \mathrm{ml}$ in anhydrous DMSO and was freshly prepared throughout the experiment.

4. In total, $50 \mathrm{ml}$ of FITC were added very slowly in 5 $\mathrm{ml}$ aliquots for every $1 \mathrm{ml}$ of protein solution, while gently and continuously stirring the protein solution.

5. After adding the entire required amount of FITC, the reaction was incubated in the dark at $4{ }^{\circ} \mathrm{C}$ for 8 hours.

6. Ammonium chloride $(\mathrm{NH} 4 \mathrm{Cl})$ was added to the solution to achieve a final concentration of $50 \mathrm{mM}$ and incubated for 2 hours at $4{ }^{\circ} \mathrm{C}$.

7. Through gel filtration, the unbound FITC was separated from the conjugate using a fine-sized gel matrix with an exclusion limit of 20,000 to 50,000 (for globular proteins such as antibodies). With the column flow stopped, the reaction mixture was carefully layered to the top of the column. Then, the column was opened, allowing the reaction mixture to flow into the column. As the mixture entered the column bed, PBS was carefully added to the top of the column and connected to a supply buffer.Two distinct bands formed on the column. The first, fast-moving band consisted of the elutes of the conjugated protein and could be observed under normal lighting conditions. The second, slower, moving band consisted of the unreacted FITC.

8. The conjugate was stored in a light-proof container at $4{ }^{\circ}$ C. Sodium azide was added as a preservative (final concentration $15 \mathrm{mM}$ ). FITC was supplied by the Pet Animals Department of the Veterinary Serum and Vaccine Research Institute (VSVRI).

9. The final product was re-titrated after conjugation using the AGID test.

\section{Protein-A- FITC}

Protein-A-FITC was commercial and lyophilized. Louis SIGMA CHEMICAL. It was used in conjunction with prepared anti-camel IgG-FITC as the control reagent.
Validation of the prepared anti-camel IgG- FITC

- Determination of protein labeling degree (DOL): The conjugates were analyzed using a UV-VIS spectrophotometer (type SPV-72, 220V, 50/60Hz, S.N.11124, Federal Republic of Germany). Quartz cuvettes were available for the 2-ml sample. In the conjugates, labeled anti-camel IgG was measured by recording the absorbance at two wavelengths, $280 \mathrm{~nm}$ and $494 \mathrm{~nm}$ (A280 and A494), which are the maximum antibody and dye absorbance.

- The (FITC) molar substitution ratio (MSR) to protein (anti-camel IgG) is called the F/P ratio. The F/P molar ratio in the conjugate, accordingly, refers to the rate of fluorescein $(\mathrm{F})$ moles to protein $(\mathrm{P})$ moles. The three equations listed below were used to calculate the F/P molar ratio in our samples.

1. Protein concentration $(\mathrm{mg} / \mathrm{mL})=[\mathrm{A} 280-$ $(0.11(\mathrm{~A} 494)] \times$ dilution factor/A280 of protein at 1 $\mathrm{mg} / \mathrm{mL}$

Where A280 and A494 are the absorbance values of the conjugated peptides at 280 and 494, respectively.0.11 is the correction factor, and the sample diluted $1: 10$ and 1.4 are the extinction coefficient of the antibodies or A280 of protein at 1 $\mathrm{mg} / \mathrm{ml}$.

2. Protein concentration $(\mathbf{M})=$ answer from Eq. $\mathbf{A} /$ protein molecular weight (Da)

Where the labeled IgG is (MW 150,000).

3. DOL (degree of labeling $)=($ moles dye $) /($ mole protein) $=\mathrm{A494} \times$ dilution factor $/ 71,000 \times$ protein concentration $(\mathrm{M})$

Where $71,000 \mathrm{~cm}-1 \mathrm{M}-1$ is the approximate molar extinction coefficient.

Protein A-FITC and the prepared rabbit anticamel IgG conjugated with FITC validated with seropositive camel anti-sera against IBR which previously titrated using SNT and are 128. Thirtyseven coverslips were cultured with (MDBK) cells overnight. The coverslips were injected with camel nasal swaps, bovine herpesvirus as positive control and one kept as negative then incubated for $1 \mathrm{hr}$ at $37^{\circ} \mathrm{C}$.

After $48 \mathrm{~h}$, the coverslips were washed with PBS and fixed in cooled acetone at $-20^{\circ} \mathrm{C}$ for $20 \mathrm{~min}$. The seropositive camel serum was incubated for $1 \mathrm{hr}$ at $37^{\circ} \mathrm{C}$. The other coverslips were stained with protein-A conjugated FITC and the prepared rabbit anti-camel IgG-conjugated FITC. The slides were examined using a fluorescent microscope to identify the variation in the number of positive samples and image clarity.

The same samples were examined using SNT and its sensitivity and specificity were both established. The sensitivity is a true positive rate, where SNT positive samples divided by total positive samples for both SNT and IFAT. The specificity is a true negative rate, where SNT negative samples divided by total negative samples for both SNT and IFAT. 


\section{Rapid Detection Of Bovine Herpes Virus Type 1......}

\section{RESULTS}

\section{Serum Neutralization Test (SNT)}

Camel sera samples were tested against BoHV-

1. Only 1 liter was used has titer 4 . The other 3 liters with a high level of BoHV-1 antibodies were neglected.

\section{The agar gel immunodiffusion (AGID) test}

After one week from the last injection in rabbits, the analysis was performed to estimate the titer of anticamel in the rabbit and check the immune level. The labeled anticamel IgG with FITC was also titrated and the result was 1000 and 625 , respectively.

\section{Validation of the prepared anti-camel IgG- FITC}

1. Estimation the degree of labeling

Protein concentration $(\mathbf{m g} / \mathbf{m L})=$

$[0.34-(0.11 \times 0.53)] \times 10 / 1.4=2 \mathrm{mg} / \mathrm{ml}$

Protein concentration $(\mathbf{M})=$

$2 / 150,000=1.3 \times 10-5 \mathrm{M}$

DOL $($ degree of labeling $)=$

$0.53 \times 10 / 71,000 \times 1.3 \times 10-5=5.3 / 0.923=5.74 \mathrm{~cm}-1 \mathrm{M}-1$

\section{Differentiation between anticamel IgG and protein A-FITC}

There was no significant difference between the slides stained with protein-A FITC and the prepared anti-camel IgG FITC either in the number of positive slides or in image clarity (figure 1). The IFAT results were compared with SNT to show the specificity and sensitivity of both anticamel $\mathrm{IgG}$ and protein A.

Thirty out of 35 nasal swabs tested positive under SNT, but 27 and 28 out of 35 nasal swabs were positive for protein-A FITC and prepared anti-camel IgG FITC, respectively. The results of the prepared anti-camel IgG FITC for the IFAT and the SNT were compared, showing $93.75 \%$ sensitivity (true positive rate) and $71.43 \%$ specificity (true negative rate) (Table 1).

Table 1: Comparison between the results of (SNT) and (IFAT) using anti-camel IgG FITC to detect (BHV-1) in camel nasal swab samples.

\begin{tabular}{|lccc|}
\hline Methods used & \multicolumn{3}{c|}{ SNT } \\
\hline $\begin{array}{l}\text { IFAT } \\
\text { protein-A }\end{array}$ & positive & negative & Total LAT \\
\hline IFAT positive & 30 & 3 & $\begin{array}{c}33 \\
(80.48 \%)\end{array}$ \\
\hline IFAT negative & 3 & 5 & $\begin{array}{c}8 \\
(19.5 \%)\end{array}$ \\
\hline Total SNT & $\begin{array}{c}33 \\
(80.48 \%)\end{array}$ & $\begin{array}{c}8 \\
(19.5 \%)\end{array}$ & $\begin{array}{c}41 \\
(100 \%)\end{array}$ \\
\hline
\end{tabular}

Figure 1: MDBK cells infected with camel nasal swab samples and stained with both protein-A- FITC and prepared anti-camel-FITC, showing a diffused intranuclear yellowish-green color
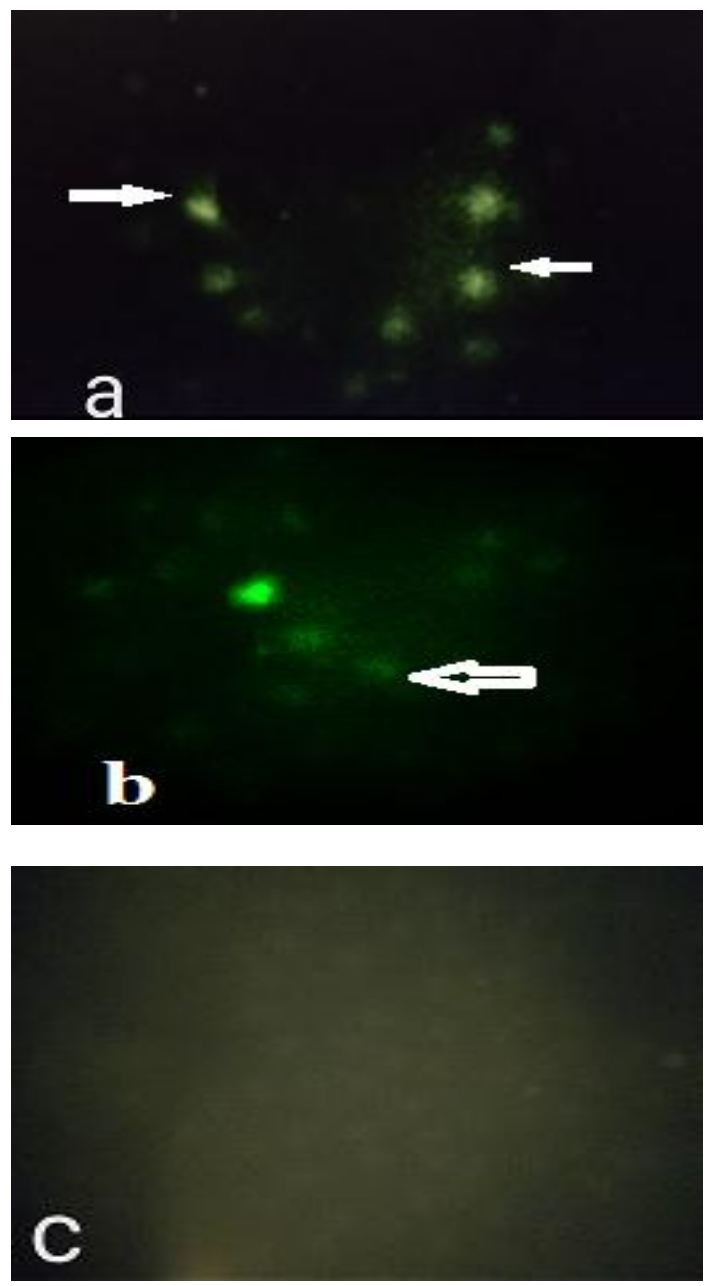

a) Slide stained with anti-camel-FITC

b) Slide stained with protein-A FITC

c) Control MDBK cells

Furthermore, when comparing the results obtained by SNT and IFAT with protein-A FITC, these showed $90.9 \%$ sensitivity and $62.5 \%$ specificity (Table 2).

Table 2: Comparison between results of (SNT) and (IFAT) using protein-A FITC to detect (BHV-1) in camel nasal swab samples.

\begin{tabular}{|lccc|}
\hline Methods used & \multicolumn{3}{c|}{ SNT } \\
\hline $\begin{array}{l}\text { IFAT } \\
\text { anti-camel }\end{array}$ & positive & negative & $\begin{array}{c}\text { Total } \\
\text { LAT }\end{array}$ \\
\hline IFAT positive & 30 & 2 & $\begin{array}{c}32 \\
(82 \%)\end{array}$ \\
\hline IFAT negative & 2 & 5 & $\begin{array}{c}7 \\
(17.9 \%)\end{array}$ \\
\hline Total SNT & $\begin{array}{c}32 \\
(82 \%)\end{array}$ & $\begin{array}{c}7 \\
(17.9 \%)\end{array}$ & $\begin{array}{c}39 \\
(100 \%)\end{array}$ \\
\hline
\end{tabular}




\section{DISCUSSION}

Camel serum with titer four was used and the others were neglected because the serum more than ten titers was considered positive for BoHV-1 Fulton et al. (1995). Camel immunoglobulin was precipitated and purified using ammonium sulfate, given its low price and large scale use (Mariam et al., 2015). The rabbits used in this study produced highly specific antibodies, responding to experimental immunizations in peripheral sites, including in the spleen and lymph nodes. Rabbits are a major source of polyclonal and monoclonal antibodies (mAbs) used in research and therapy (Esteves et al., 2018).

Montanide oil 206 was used because it is very fluid, stable, well-tolerated and induces a short and long term immune response (Mohi-ud-din et al., 2014). They are also useful as traditional Freund's adjuvant in enhancing immune responses in mice (Yang et al., 2010). The subcutaneous route is better than the intramuscular one because there are no ulcerative lesions; it is, therefore, less painful to the experimental subjects and causes the slow release of camel IgG (Blanc et al., 2009).

AGID test was used in our study because not only is it available easy cheap test, but also it is the only test that can estimate the level of both anticamel IgG and labeled anticamel with FITC. SNT can't be used because fluorescein has toxic effects on cell culture (Alford $\boldsymbol{e t}$ al., 2009). AGID sensitivity was $57 \%$ and specificity was $92.5 \%$. The positive predictive value was calculated in $85.7 \%$ for a confidence interval of 95\%. (Ferreira et al., 2002).

The concentration of protein labeled in the conjugate was $2 \mathrm{mg} / \mathrm{ml}$ and successful labeling was likely to occur if the starting concentration was > 1 $\mathrm{mg} / \mathrm{mL}$ (Molecular Probes 2006). The degree of labeling conjugate was 5.74 and the optimal DOL usually falls between 2 and 10 (AAT Bioquest, Inc., 2020). The sensitivity of anticamel was $93.75 \%$ and 90.9\% in protein A; these results agreed with (Hanan et al., 2004) which revealed that the sensitivity of protein-A less than anticamel $\mathrm{IgG}$ as protein-A conjugate failed to detect 3 cases of the positive sera. The highest prevalence of natural infectious bovine rhinotracheitis virus (BoHV-1) was observed in the sera of dromedary camels in Sudan (Zhou et al., 2017), so we should have a rapid test such as IFAT to diagnosis dromedary camels come from Sudan.

\section{CONCLUSION}

This study provides a suitable rapid method to diagnose BoHV-1 in camels, using prepared rabbit anti-camel IgG -conjugated with fluorescein and other commercial product. But, unfortunately, it will be used only in laboratories having a fluorescent microscope to prevent the spread of the BoHV-1 from the Sudanese and Somalia imported camels to the herds in Egypt, causing abortion and economic losses.

\section{ACKNOWLEDGMENTS}

For the spirit of Prof Dr. Mohammed Saad (Animal Reproductive Research Institute (ARRI), for his collaboration and assistance, and we pray to Allah to forgive him. The authors also thank Prof Dr. Hanaa Mohammad Ghoneim, Animal Reproduction Research Institute (ARRI), Agriculture Research Center (ARC), Giza, Egypt, for his help and collaboration. Thanks a lot for Prof Dr. Mohamed khodier, veterinary serum and vaccine research institute (VSVRI), Abassia, Egypt for providing us with Fluorescein isothiocyanate.

\section{REFERENCES}

AAT BIOQUEST, INC. 2020. January 04, Quest Calculate ${ }^{\mathrm{TM}}$ Degree of Labeling (DOL) Calculator." Retrieved from https://www.aatbio.com/tools/degreeof-labeling-calculator

ABD EI HAFEZ, S.M., ANWAR, A.M., IBRAHIM, A.M., MAHMOUD, M.B., and HASSAN, H. M. 2010. Preparation of fluoresce isothiocyanate conjugated IgG (FITC) anti-camel and anti-buffalo., Journal of Natural Sciences 8: 342-347.

ALFORD R, SIMPSON HM, DUBERMAN J, HILL GC, OGAWA M, REGINO C, KOBAYASHI H, CHOYKE PL. 2009. Toxicity of organic fluorophores used in molecular imaging: a literature review. Molecular Imaging. 2009 Dec; 8(6):341-54.

ANDREW, J. DAVISON, 2010. Herpesvirus systematics. Vet Microbiol. 143(1-2): 52-69.

ASLAM, B., HUSSAIN, I., MAHMOOD, M. S., and KHAN, A. 2013. Preparation and evaluation of Montanide ISA 206 adjuvanted bacterin of Borrelia anserine in laying chickens. The Journal of Applied Poultry Research196-203.

BLANC, M.R, ANOUASSI, A, ABED M.A, CANÉPA, S, LABAS, V, and BRUNEAU, G. 2009. A new method to discriminate immunogen-specific heavy-chain homodimer form heterotetramer immunoglobulin $G$ directly in immunized dromedary whole plasma proteins: Western ligand blotting. Veterinary immunology and immunopathology journal.127:340-9.

ESTEVES, P., ABRANTES, J., BALDAUF, H., BENMOHAMED, L., CHEN, Y., CHRISTENSEN, N., GONZÁlEZ-GALLEGO, J., GIACANI, L., HU, J., KAPLAN, G., and KEPPLER, O. T. 2018. The wide utility of rabbits as models of human diseases. Experimental \& Molecular Medicine. 50:1-10.

FERREIRA R., FONSECA LS., and LILENBAUM W. 2002. Agar gel immunodiffusion test (AGID) evaluation for detection of bovine paratuberculosis in Rio de Janeiro, Brazil. Applied Microbiology 2002, 35, 173-175

FULTON, R. W., CONFER, A. W., BURGE, L. J., PERINO, L. J., D'OFFAY, J. M., PAYTON, M. E., and MOCK, R. E. 1995. Antibody responses by cattle after vaccination with commercial viral vaccines containing bovine herpesvirus 1 , bovine viral diarrhea virus, parainfluenza-3 virus, and bovine respiratory syncytial virus immunogens and subsequent 
revaccination at day 140 . Vaccine, Vol. 13 , No. 8. pp. 725-733

HANAN M.M. EI-HUWAIRY, WAHID M. MOUSSA, ALY A., EL-ABEIDY, and SALAH A. SELIM. 2004. Preparation of anti-camel immunoglobulin-G conjugated with fluorescin isothiocyanate and alkaline phosphatase. 1rst Ann. Conf., FVM. Moshtohor, Sept 2004.

HELENA B., 2018. Where does the long "journey" of the camels go? dA.Derecho Animal (Forum of Animal Law Studies) 9/4: 62-7.

INTISAR KS, ALI YH, KHALAFALLA AI, MAHASIN EA, AMIN AS.2009. Natural exposure of Dromedary camels in Sudan to the infectious bovine rhinotracheitis virus (bovine herpes virus-1). Acta Trop.; 111(3):243-6.

LAEMMLI, U. K., 1970. Cleavage of structural protein during the assembly of the head of bacteriophage T4. Nature Journal, 227: 680-685.

LOWRY, O. H., ROSEBROUGH, N. J., FARR, A. L., and Randall, R. J. 1951. Protein measurement with the folin phenol reagent. Journal of biological chemistry 193: 265-275.

MADHAVAN, H. N. 1, PRIYA, K, MALATHI, J., and JOSEPH, P. R. 2003. Laboratory methods in the detection of herpes simplex virus (HSV) in keratitis--a 9year study including polymerase chain reaction (PCR) during the last 4 years. Indian journal of pathology \& microbiology 4: 109.

MARIAM, S. H. S, OOI, C. W, TAN, W. S, JANNA, O. A, ARBAKARIY, A. A., and TEY B. T. 2015. Purification of rabbit polyclonal immunoglobulin $\mathrm{G}$ with ammonium sulphate precipitation and mixed-mode chromatography. Separation and Purification Technology Journal 144: 133

MARTINELLE, L., DAL POZZO, F., SARRADIN, P. DE LEEUW, I, DE CLERCQ, K., THYS, C., ZIANT, D., THIRY, E., and SAEGERMAN, C. 2011. Two alternative inocula to reproduce bluetongue virus serotype 8 disease in calves. Vaccine. 29:3600-9.

MESSENGER, S., and RUPPRECHT, C. E. 2015. An indirect fluorescent antibody test for the serological detection of rabies virus immunoglobulin $\mathrm{g}$ and immunoglobulin $\mathrm{m}$ antibodies. In Current Laboratory Techniques in Rabies Diagnosis, Research and Prevention 2: 157-173.

MOHI-UD-DIN, M., MUDASSER, H., ZAHID, I., and IFTIKHAR, H. 2014. Immune response of rabbits to hemorrhagic septicemia vaccine formulations adjuvanted with montanide ISA-206, paraffin oil, and alum. Asian Journal of Agriculture and Biology 2:161.

MOLECULAR PROBES 2006. Alexa Fluor ® 488 Microscale Protein Labeling Kit (A30006). http://tools.thermofisher.com/content/sfs/manuals/mp3 0006.pdf.

NATIONAL RESEARCH COUNCIL (US) INSTITUTE FOR LABORATORY ANIMAL RESEARCH. 2004. The Development of science-based Guidelines for Laboratory Animal Care: Proceedings of the November 2003 International workshop. Washington (DC): National Academies Press (US); D:, International Guiding Principles for Biomedical Research Involving Animals (1985) Available from : https://www.ncbi.nlm.nih.gov/books/NBK25438
OIE, 2018. Infectious bovine rhinotracheitis/infectious pustular vulvovaginitis

(IBR/IPV). Chapter 3.4.11. https://www.oie.int/fileadmin/Home/eng/Health_standards/ta hm/3.04.11 IBR IPV.pdf

OUCHTERLONY, O., 1962. Progress in allergy. Vol. 2, PP. 30-134, Basel, Karger.

RAOOFI, A., HEMMATZADEH, F., and GHANAEI, A. M. 2012. A serological survey in camels (Camelus dromedarius) to detect antibodies against bovine herpesvirus type-1 and Mycobacterium avium paratuberculosis in Iran. Journal of Camel Practice and Research 19: 65-8.

RAAPERI, K., ORRO, T. AND VILTROP, A. 2014. Epidemiology and control of bovine herpesvirus 1 infection in Europe. Veterinary Journal (London, England: 1997), 201(3):249-256.

SUNIL-CHANDRA, N.P. 2000. Viral infections of buffaloes. Rotaviruses and herpes viruses. Proc. of the Third Asian Buffalo Congress on the Changing Role of the Buffalo in the New Millennium in Asia, Sri Lanka, 27-31 Mar.: 255-261.

TENDLER, M., PINTO, R. M., LIMA, ADE O., SAVINO, W., and KATZ, N. 1991. Vaccination in murine schistosomiasis with adult worm-derived antigens: variables influencing protection in outbred mice. International journal for parasitology 21: 299.

VAN OIRSCHOT J.T., STRAVER P.J., VAN LIESHOUT J.A., QUAK J., WESTENBRINK F., VAN EXSEL A.C. A. 1993. subclinical infection of bulls with bovine herpesvirus type 1 at an artificial insemination centre. Vet Rec.; 132:32-35.

VIRA, S., MEKHEDOV, E., HUMPHREY, G., and BLANK, P. S. 2010. Fluorescent labeled antibodies balancing functionality and degree of labeling. Analytical biochemistry 402: 146-50.

YANG, J., GU, Y., YANG, Y, WEI, J, WANG, S, CUI, S, PAN, J, LI, Q., and ZHU, X. 2010. Trichinella spiralis immune response and protective immunity elicited by recombinant paramyosin formulated with different adjuvants. Experimental parasitology 124: 403-8.

ZHOU, H., TOURKAKIS, G., SHI, D., KIM, D. M., ZHANG, H., Du, T., EADES, W. C., and BEREZIN, M. Y. 2017. Natural exposure of Dromedary camels in Sudan to the infectious bovine rhinotracheitis virus (bovine herpes virus-1). Acta Tropica 111:243-6.

How to cite this article:

Ramzy, H. Hamouda And Marwa F. Mahmoud.2020. Rapid Detection Of Bovine Herpes Virus Type 1 (Bohv-1) In Egyptian Dromedary Camels. Journal of Applied Veterinary Sciences, 5(2): 61-66.

DOI: HTTPS://DX.DOI.ORG/10.21608/JAVS.2020.85587 